\title{
Should I Get LASIK If I'm Breastfeeding?
}

Majid Moshirfar - David B. Rosen - Madeline B. Heiland •

Yasmyne C. Ronquillo · Phillip C. Hoopes

Received: May 24, 2019 / Published online: June 28, 2019

(C) The Author(s) 2019

\begin{abstract}
Changes in keratometric values and refraction can occur during pregnancy. For this reason, changing a patient's refractive prescription or undergoing corneal refractive surgery is not recommended during pregnancy. However, the extent to which these corneal changes persist during lactation is not as well reported. Pregnancy and lactation lead to hormonal changes that affect the corneal structure. LASIK, or other types of refractive surgery, is not recommended until all of the following conditions are met: cessation of lactation, the return of regular menses, and a return to pre-pregnancy refraction. Additionally, patients should be cautioned that refractive regression may occur if they become pregnant within 1 year of LASIK.
\end{abstract}

Enhanced digital features To view enhanced digital features for this article go to https://doi.org/10.6084/ m9.figshare.8294714.

M. Moshirfar

John A. Moran Eye Center, Department of

Ophthalmology and Visual Sciences, University of

Utah School of Medicine, Salt Lake City, UT, USA

M. Moshirfar

Utah Lions Eye Bank, Murray, UT, USA

M. Moshirfar $(\varangle)$ · Y. C. Ronquillo · P. C. Hoopes Hoopes Durrie Rivera Research Center, Hoopes Vision, Draper, UT, USA

e-mail: cornea2020@me.com

D. B. Rosen - M. B. Heiland

The University of Arizona College of Medicine, Phoenix, AZ, USA
Funding: Research to Prevent Blindness, NY, USA.

Keywords: Breastfeeding; Cornea; Lactation; LASIK; Post-partum

The female body undergoes many drastic changes during pregnancy. While some of these changes are apparent, others are harder to detect-for both observers and patients. Corneal changes fall into the latter category. While LASIK during pregnancy is contraindicated [1], our purpose is to discuss corneal changes that start in pregnancy and persist through lactation and to provide recommendations for performing corneal refractive surgery in the post-partum period.

While hormone levels in pregnancy can vary based on the individual, there is a significant increase in progesterone and several forms of estrogen (including estradiol and estrone) [2, 3]. Estrogen and progesterone levels return to prepregnancy values within a few days after delivery [3]. This decline in estrogen and progesterone levels disinhibits prolactin so that lactation occurs shortly after [4]. Oxytocin also regulates the let-down of milk [5]. If milk removal is not sufficient, pro-lactation hormone levels decline due to the release of an inhibitor [6]. If a woman does not breastfeed after delivery, it usually takes around 6 weeks for menses to return [7]; however, if a woman is 
breastfeeding, she will not see a return of menses for 6-9 months, on average $[8,9]$.

The human cornea has sex-hormone receptors to estrogen, progesterone, and androgen [10]. The activity of these receptors is thought to drive hormonally mediated corneal changes during times of hormonal fluctuation, from menstruation [11] to pregnancy to menopause [12].

Corneal thickness changes during pregnancy [13]. This thickening effect is postulated to be secondary to water retention [13]. However, there is conflicting evidence, with Kilavuzoglu et al. [12] reporting no significant change in corneal thickness during pregnancy or lactation. There is evidence that a change in corneal thickness occurs during the third trimester when estrogen and progesterone levels are very high, but that this change does not persist in the post-partum period [14].

Corneal curvature is another parameter that changes during pregnancy [15]. One study noted that steepening of the corneal front steep $K$ value was the only significant value that changed during pregnancy [16]. Similar to corneal thickness, this change in $K$ value was not consistent in all studies [12]. Changes in curvature seem to persist throughout lactation but are less marked than during pregnancy [15]. This difference suggests that prolactin may play a role in corneal morphologic changes, although no prolactin receptor has yet been found in the human cornea.

These topographic changes may or may not result in refractive changes. Not all pregnant or lactating women notice a change in their vision $[17,18]$. In women who did complain of visual changes during pregnancy, a myopic shift was documented [17]. Most patients had improvement of their myopic shift by 15 weeks postpartum. Complete resolution occurred in only $8 \%$ of participants through the course of the study (5-24 weeks post-partum). It was not reported whether the patients were breastfeeding during the post-partum period. A similar study reported myopic shifts with a complete return to pre-pregnancy acuity during the postpartum period in the majority of patients [19]; there was also no mention of whether the patients were breastfeeding during the postpartum period of observation.

Decreased tear production is another change associated with pregnancy [20]. While the exact mechanism of this effect is not entirely understood, animal models show changes to ion transporters in the lacrimal ducts during pregnancy [21]. In addition, certain forms of estrogen increase pro-inflammatory cytokine production in human corneal epithelial cells [22]. A combination of these factors most likely leads to an increased incidence of dry eye in pregnancy [20]. Because dry eye disease is a common side effect of LASIK [23], tear quality and production should be adequate before considering LASIK during the post-partum period. Furthermore, a patient's pregnancy after a LASIK procedure may further reduce tear production. If a patient who had LASIK becomes pregnant and complains of dry eye symptom, there should be a low threshold for initiating treatment (the use of punctal plugs).

While there is a limited amount of data on LASIK outcomes in lactating patients, there have been several studies on photorefractive keratectomy (PRK) during pregnancy. One study found refractive changes in patients who became pregnant shortly after PRK [24], and another reported a case with similar results, where refraction returned to baseline after a spontaneous abortion [25]. However, another study reported satisfactory refractive results in patients who underwent PRK during pregnancy [26]. A study reported visual changes in pregnant patients who either had LASIK previously or had no history of refractive surgery, and found that the magnitude of visual change during pregnancy was inversely proportional to the degree of refraction corrected by LASIK [27]. However, the group who had LASIK prior to pregnancy showed more significant changes in their refraction than the women who did not undergo refractive surgery. This change in refraction among participants who had LASIK could be related to the loss of estrogen receptors that is directly proportional to the area of corneal resurfacing. There have also been reports of keratectasia in pregnant patients who had previously undergone LASIK [28, 29]. Although this is a rare finding, Hafezi et al. [28] suggested 
that LASIK and pregnancy could trigger keratectasia in predisposed patients and that increased estrogen could reduce the biomechanical stability of corneal stroma.

In summary, changes in corneal parameters and refraction are relatively well described during pregnancy, but the degree of persistence of these effects during lactation is less evident. We do not recommend LASIK for lactating women. Although menstruation may resume while a patient is still lactating, we do not recommend using the return of a baseline menstrual cycle as an adequate marker for deciding that LASIK may be performed. Until the effects of prolactin on the cornea are better established, we recommend waiting for complete cessation of lactation before LASIK is performed. Also, evidence that refraction has returned to pre-pregnancy values is essential [30]. While it is clear that pregnancy is a contraindication to LASIK [1], we suggest that during lactation, the risks of LASIK outweigh the benefits. We also recommend informing patients who have recently undergone LASIK that pregnancy within a year after the procedure could result in an increased risk of refractive regression [30].

\section{ACKNOWLEDGEMENTS}

Funding. Research to Prevent Blindness, NY, USA.

Authorship. All named authors meet the International Committee of Medical Journal Editors (ICMJE) criteria for authorship for this article, take responsibility for the integrity of the work as a whole, and have given their approval for this version to be published.

Disclosures. Majid Moshirfar, David B. Rosen, Madeline B. Heiland, Yasmyne C. Ronquillo, and Phillip C. Hoopes have nothing to disclose.

Compliance with Ethics Guidelines. This article is based on previously conducted studies and does not contain any studies with human participants or animals performed by any of the authors.

Open Access. This article is distributed under the terms of the Creative Commons Attribution-NonCommercial 4.0 International License (http://creativecommons.org/licenses/ by-nc/4.0/), which permits any noncommercial use, distribution, and reproduction in any medium, provided you give appropriate credit to the original author(s) and the source, provide a link to the Creative Commons license, and indicate if changes were made.

\section{REFERENCES}

1. Woreta $\mathrm{KB}$, Woreta F. Update on contraindications for laser-assisted in situ keratomileusis and photorefractive keratectomy. Curr Opin Ophthalmol. 2014;25(4):251-7. https://doi.org/10.1097/icu. 0000000000000055 .

2. Tal R, Taylor HS, Burney RO, Mooney SB, Giudice LC. Endocrinology of pregnancy. MDText.com, Inc.; 2000. http://www.ncbi.nlm.nih.gov/pubmed/ 25905197. Accessed 18 May 2019.

3. Hendrick V, Altshuler LL, Suri R. Hormonal changes in the postpartum and implications for postpartum depression. Psychosomatics. 1998;39(2):93-101. https://doi.org/10.1016/S0033-3182(98)71355-6.

4. Ostrom KM. A review of the hormone prolactin during lactation. Prog Food Nutr Sci. 1990;14(1):1-43. http://www.ncbi.nlm.nih.gov/ pubmed/2092340. Accessed 18 May 2019.

5. The physiological basis of breastfeeding. 2009 . https://www.ncbi.nlm.nih.gov/books/NBK148970/. Accessed 19 May 2019.

6. Pillay J, Davis TJ. Physiology, lactation. StatPearls Publishing; 2019. http://www.ncbi.nlm.nih.gov/ pubmed/29763156. Accessed 19 May 2019.

7. Jackson E, Glasier A. Return of ovulation and menses in postpartum nonlactating women. Obstet Gynecol. 2011;117(3):657-62. https://doi.org/10. 1097/AOG.0b013e31820ce18c.

8. Gross BA, Burger H, WHO Task Force on methods for the natural regulation of fertility. Breastfeeding patterns and return to fertility in Australian women. Aust N Z J Obstet Gynaecol. 2002;42(2):148-154. http://www.ncbi.nlm.nih. gov/pubmed/12069140. Accessed 19 May 2019. 
9. McNeilly AS. Lactational control of reproduction. Reprod Fertil Dev. 2001;13(7-8):583-590. http:// www.ncbi.nlm.nih.gov/pubmed/11999309. Accessed 19 May 2019.

10. Suzuki T, Kinoshita Y, Tachibana M, et al. Expression of sex steroid hormone receptors in human cornea. Curr Eye Res. 2001;22(1):28-33. https://doi. org/10.1076/ceyr.22.1.28.6980.

11. Kiely PM, Carney LG, Smith G. Menstrual cycle variations of corneal topography and thickness. Am J Optom Physiol Opt. 1983;60(10):822-829. http:// www.ncbi.nlm.nih.gov/pubmed/6650653. Accessed 19 May 2019.

12. Bahadir Kilavuzoglu AE, Cosar CB, Bildirici I, Cetin $\mathrm{O}$, Ozbasli E. Estrogen- and progesterone-induced variation in corneal parameters according to hormonal status. Eye Contact Lens Sci Clin Pract. 2017;44(Suppl 1):1. https://doi.org/10.1097/ICL. 0000000000000376.

13. Weinreb RN, Lu A, Beeson C. Maternal corneal thickness during pregnancy. Am J Ophthalmol. 1988;105(3):258-260. http://www.ncbi.nlm.nih. gov/pubmed/3344782. Accessed 14 May 2019.

14. Ataş M, Duru N, Ulusoy DM, et al. Evaluation of anterior segment parameters during and after pregnancy. Cont Lens Anterior Eye. 2014;37(6):447-50. https://doi.org/10.1016/j.clae.2014.07.013.

15. Park SB, Lindahl KJ, Temnycky GO, Aquavella JV. The effect of pregnancy on corneal curvature. CLAO J. 1992;18(4):256-259. http://www.ncbi.nlm. nih.gov/pubmed/1424062. Accessed 14 May 2019.

16. Goldich Y, Cooper M, Barkana Y, et al. Ocular anterior segment changes in pregnancy. J Cataract Refract Surg. 2014;40(11):1868-71. https://doi.org/ 10.1016/j.jcrs.2014.02.042.

17. Pizzarello LD. Refractive changes in pregnancy. Graefe's Arch Clin Exp Ophthalmol. 2003;241(6):484-8. https://doi.org/10.1007/ s00417-003-0674-0.

18. Manges TD, Banaitis DA, Roth N, Yolton RL. Changes in optometric findings during pregnancy. Am J Optom Physiol Opt. 1987;64(3):159-166. http://www.ncbi.nlm.nih.gov/pubmed/3578480. Accessed 14 May 2019.

19. Mehdizadehkashi K, Chaichian S, Mehdizadehkashi A, et al. Visual acuity changes during pregnancy and postpartum: a cross-sectional study in Iran. J Pregnancy. 2014;2014:675792. https://doi.org/10. $1155 / 2014 / 675792$.

20. Imafidon CO, Imafidon JE. Contact lenses in pregnancy. BJOG An Int J Obstet Gynaecol.
1992;99(11):865-8. https://doi.org/10.1111/j.14710528.1992.tb14429.x.

21. Huang J, Lu M, Ding C. $\mathrm{Na}^{+} / \mathrm{K}^{+}$-ATPase expression changes in the rabbit lacrimal glands during pregnancy. Curr Eye Res. 2013;38(1):18-26. https://doi. org/10.3109/02713683.2012.725797.

22. Suzuki T, Sullivan DA. Estrogen stimulation of proinflammatory cytokine and matrix metalloproteinase gene expression in human corneal epithelial cells. Cornea. 2005;24(8):1004-1009. http://www. ncbi.nlm.nih.gov/pubmed/16227852. Accessed 20 May 2019.

23. Yu EY, Leung A, Rao S, Lam DS. Effect of laser in situ keratomileusis on tear stability. Ophthalmology. 2000;107(12):2131-2135. http://www.ncbi.nlm. nih.gov/pubmed/11097583. Accessed 20 May 2019.

24. Sharif K. Regression of myopia induced by pregnancy after photorefractive keratectomy. J Refract Surg. 1997;13(5):S445-6. https://doi.org/10.3928/ 1081-597X-19970801-13.

25. Starr MB. Pregnancy-associated overcorrection following myopic excimer laser photorefractive keratectomy. Arch Ophthalmol (Chicago, Ill 1960). 1998;116(11):1551. http://www.ncbi.nlm.nih.gov/ pubmed/9823373. Accessed 19 May 2019.

26. Hefetz L, Gershevich A, Haviv D, Krakowski D, Eshkoly M, Nemet P. Influence of pregnancy and labor on outcome of photorefractive keratectomy. J Refract Surg. 12(4):511-512. http://www.ncbi. nlm.nih.gov/pubmed/8771547. Accessed 19 May 2019.

27. López-Prats MJ, Hidalgo-Mora JJ, Sanz-Marco E, Pellicer A, Perales A, Díaz-Llopis M. Influencia del embarazo sobre los parámetros refractivos tras cirugía laser in situ keratomileusis. Arch Soc Esp Oftalmol. 2012;87(6):173-8. https://doi.org/10. 1016/j.oftal.2011.09.021.

28. Hafezi F, Iseli HP. Pregnancy-related exacerbation of iatrogenic keratectasia despite corneal collagen crosslinking. J Cataract Refract Surg. 2008;34(7):1219-21. https://doi.org/10.1016/j.jcrs. 2008.02.036.

29. Hafezi F, Koller T, Derhartunian V, Seiler T. Pregnancy may trigger late onset of keratectasia after LASIK. J Refract Surg. 2012;28(4):242-3. https://doi. org/10.3928/1081597X-20120401-07.

30. Dinn RB, Harris A, Marcus PS. Ocular changes in pregnancy. Obstet Gynecol Surv. 2003;58(2):137-44. https://doi.org/10.1097/01. OGX.0000047741.79433.52. 